UDC 340.12

DOI https://doi.org/10.32849/2663-5313/2020.10.36

\title{
Veronika Horielova,
}

Candidate of Legal Sciences, Associate Professor,

Associate Professor at the Department of State Legal Sciences

University of economy and right "KROK"

\section{CONCEPTUAL TRENDS OF MODERN MORALITY IN LEGAL SOCIETY}

The article is devoted to the analysis of the current state of morality in the legal society. Observing the transformation of the content of morality, which is a special state in the mobile process of social development and is progressing at the turn of political and socio-economic transformations. We can say that the transformation of morality in law is a transformation of public opinion of different meaning and direction, which due to internal or external factors or a combination of them are reproduced in the rules of law. The transformation of morality occurs at certain stages of development of society, and especially at those points in time when people are very sensitive to any external changes. In such periods, the general morality of society may be on a new countdown and lead to changes in directions to its further evolutionary path. Such a transformation of morality cannot exist outside the law and not affect its content. The article examines current trends in the transformation of morality in a legal society, which give rise to new theoretical constructions and approaches in relations in society, and thus encourage the modernization of legal tablets. The article analyzes the materials of statistical research on the viewes on the morals of the younger generation and the elderly. The tendency of gradual degradation of moral foundations is traced. The article states that certain provisions of the Law of Ukraine "On Protection of Public Morality" are unconstitutional, although they coincide with the requirements of the European Convention for the Protection of Human Rights and Fundamental Freedoms. It is emphasized that the Law of Ukraine "On Protection of Public Morality" does not fulfil its function, because it lacks many necessary factors that need attention, and its provisions should not be perceived as a restriction of freedom of expression for man, as freedom of legal the state is possible only within the framework of observance of the law and norms of morality. The article emphasizes that the content of the category "rule of law" implies the filling of legal norms with several moral principles and principles, because otherwise, the state can not be called legal. The article substantiates and proposes the category of "stabilizing function of morality" as a new moral and legal category, which is to maintain the stability of basic principles and rules of human life within the state through public resources, social, humanitarian, educational, propaganda and other methods of influence.

Key words: transformation of morality, stabilizing function of morality, law, moral standards, good, evil.

Formulation of the problem. The global moral transformations of the modern world cannot but be reflected in the legal field. In the last decade, Ukraine has undergone many changes in almost all dimensions: economic, political, social, etc. and all of them have left their mark on the spiritual sphere of the individual. Modern trends in the transformation of morality in society give rise to new theoretical constructions and approaches in relations in society, modernizing the legal tablets. Given this, it is necessary to study and identify these changes.

This article examines the latest theoretical concepts of scientists Ljupco Ristovski, Kim Parker, Ruth Igielnik, Gregory A. Smith, etc., and statistical achievements (Pew study), as well as the views of modern Ukrainian researchers.

Modern changes that are taking place not only in Ukraine but also around the world need theoretical understanding to offer modern theory of law the latest paradigms and moral and legal constructions.
Formulating the goals of the article. The purpose of the article is: to identify the features and patterns of moral transformation in society; substantiate the existence of a new category "stabilization function of morality" as a new legal category, and provide its definition; to analyze whether the gradual degradation of moral foundations is connected with the expansion of human rights.

Presentation of the main research material. If at first the top point of immorality was the violation of the Ten Commandments of God, then in the VI century were listed only seven peaks (mortal sins) of immoral acts, such as pride, jealousy, anger, laziness, greed, gluttony and lust. Already in the Soviet era of the communist era, these immoral acts began to be called no more than "bad character", today - it is "individual handwriting". Thus, humanity is exposing a new religion - man-worshipers, where they believe that man can be highly moral regardless of faith 
in God. Thus, we observe the transformation of the content of morality, which is a special state in the mobile process of social development, and special breaks are seen here as periods of political change and socio-economic transformation. Morality does not disappear, it is constantly transformed under the influence of various ideas, which are born due to heterogeneity in views on good and evil, due to spiritual imbalance and uncertainty, the commitment to change in the "fashion to be good or evil". We can say that the transformation of morality in law is a transformation of public opinion of different meaning and direction, which due to internal or external factors or a combination of them are reproduced in the rules of law. The transformation of morality occurs at certain stages of development of society, and especially at those points in time when people are very sensitive to any external changes. In such periods, the general morality of society may be on a new countdown and lead to a change in the direction of its further evolutionary path. In this case, human perception of the moral and immoral passes first the stage of general evaluation and as an accepted fact lies in the legal sources. For example, in family law, the prerequisite for the legality of marriage in pre-revolutionary times (before 1917) was the presence of a church blessing, and the law protected only those family relationships between a man and a woman that were sanctified by the mystery of marriage. Such a marriage could be created only once in a lifetime for one person. In 1919, as a result of the advent of ungodly power, a marriage entered into in a state body became legal, and a marriage entered into according to a religious rite no longer had legal consequences. Such a marriage was allowed to be created many times in the life of one person. Since 2002, Ukraine's Family Law has tried to equate "de facto marriage" with registered marriage, which in effect means that marriage is not mandatory at all. And the question of the possibility of same-sex marriage is already on the line. In this connection, the question arises: can such changes be called the development of morality or do we trace its decline? But can the expansion of human rights contribute to the gradual degradation of moral foundations?

Pew's research indicates that a non-believer (atheist) is more likely than a believer to believe in the existence of "absolute standards of right and wrong" - that is, moral and immoral. Thus, researchers believe that atheism in itself does not undermine morality, although the idea of the morality of a non-believer may differ from the idea of the morality of the believer [1]. In our opinion, this conclusion shows the desire of researchers to prove the old truth as the world: the existence of man trying to change himself (believer) and the existence of man (atheist) trying to create convenient external rules of coexistence. Speaking of improving the standards of behaviour of persons on whose activities the lives of others depend, and where there is the most likely violation of human rights (law enforcement, court, bar, detective work, medicine) we are interested despite all external standards of morality, violation of which should be punished. After all, it does not matter whether a person is a believer or not, it does not matter whether his inner nature supports the written rules of morality, it is important that a person must know the standards of morality and act in accordance with them. For example, a law enforcement officer who has his individual views on morality, acts morally - correctly, ignoring their own needs or considerations, makes choices within the moral standards of their profession. In other words: no matter what morality a person lives with, he must fully enter the moral and legal field of the profession he has chosen. Thus, the moral standard is the conditions and rules of society, which are accepted as a duty and fulfilled. it does not matter whether his inner nature supports the written rules of morality, it is important that a person must know the standards of morality and act in accordance with them. For example, a law enforcement officer who has his own individual views on morality, acts morally - correctly, ignoring their own needs or considerations, makes choices within the moral standards of their profession. In other words: no matter what morality a person lives with, he must fully enter the moral and legal field of the profession he has chosen. Thus, the moral standard is the conditions and rules of society, which are accepted as a duty and fulfilled. it does not matter whether his inner nature supports the written rules of morality, it is important that a person must know the standards of morality and act in accordance with them. For example, a law enforcement officer who has his individual views on morality, acts morally - correctly, ignoring their own needs or considerations, makes choices within the moral standards of their profession. In other words: no matter what morality a person lives with, he must fully enter the moral and legal field of the profession he has chosen. Thus, the moral standard is the conditions and rules of society, which are accepted as a duty and fulfilled. neglecting his own needs or considerations, makes choices within the moral standards of his profession. In other words: no matter what morality a person lives with, he must fully enter the moral and legal field of the profession he has chosen. Thus, the moral standard is the conditions and rules of society, which are accepted as 
a duty and fulfilled. neglecting his own needs or considerations, makes choices within the moral standards of his profession. In other words: no matter what morality a person lives with, he must fully enter the moral and legal field of the profession he has chosen. Thus, the moral standard is the conditions and rules of society, which are accepted as a duty and fulfilled.

As for the participatory world, American researchers have found that the percentage of believers decreases every year [2]. At the same time, the percentage of supporters of homosexuality and same-sex marriage among non-believers is increasing [3]. Thus, the published materials of statistical research have shown that the younger generation (48\%) and middle-aged people $(47 \%)$ believe that it would be morally correct and even useful for society to legalize same-sex marriage. As a result, the younger generation has experienced such a decline that most (59\%) find it convenient to use gender-neutral pronouns, and believe that the paper form of documents or online profile should include additional gender options (options) in addition to "man" and "woman" [4]. All of the above creates an arena, on which the younger generation demonstrates its understanding of the moral world and being, and thus we can predict what the picture of morality will look like not in some distant future, but only in 5-10 years. However, any views and judgments on things are capable of constant change and transformation, and it is hoped that the old moral values will remain desirable for all in the future and human life will be based on these values. Thus, American researchers have traced another trend: young people - believers - are characterized by mourning for the poor, sick, suffering. Their constant gratuitous participation in charitable voluntary organizations is noted [5]. any views and judgments on things are capable of constant change and transformation, and there is hope that the old moral values will remain desirable for all in the future and human life will be based on these values. Thus, American researchers have traced another trend: young people - believers - are characterized by mourning for the poor, sick, suffering. Their constant gratuitous participation in charitable voluntary organizations is noted [5]. any views and judgments on things are capable of constant change and transformation, and there is hope that the old moral values will remain desirable for all in the future and human life will be based on these values. Thus, American researchers have traced another trend: young people believers - are characterized by mourning for the poor, sick, suffering. Their constant gratuitous participation in charitable voluntary organizations is noted [5].
The older generation sees morality as the source from which moral debt to society originates. According to modern scientist Ljupco Ristovski "if people are created by God's choice, then they have a stable moral foundation, due to which they are created to live morally from the very beginning of life - developing such people control their own character according to these innate moral postulates" [6, p 84]. Further, the scientist concludes that he who does not believe in God does not have a stable knowledge of justice and justice, because such a person is not given criteria for determining what is good and what is bad, what is moral and what is immoral [6, p. 86]. We fully support this opinion, because a believing person (I mean an Orthodox Christian) who from an early age carries those moral statutes, of which humanity can only dream, cannot renounce them and act immorally. And thus the true statement of the scientist "morality originates from man" [6, p. 87]. In other words, what a person has inside himself will come out of him and he will propagate as evil or good, moral and immoral.

The moral face of modern Ukraine is quite ambiguous, but one thing is for sure: today there is an extremely wide range of views on morality. The transformation of morality in Ukraine is carried out primarily under the influence of the public and media spheres. Thus, according to lawyers, in the formation of moral qualities of the person the main role is played by "generally accepted, acceptable model of behaviour in society", which, along with age-old Christian Ukrainian values, is now deformed under the influence of Hollywood movies with their widespread violence, Moscow gangsters TV programs, immoral advertising [7, p. 14]. It can be concluded that some responsibility for the level and content of morality rests with the Ukrainian media, which promotes immorality.

The Law of Ukraine "On Protection of Public Morality" establishes the legal basis for the protection of society from the distribution of products that adversely affect public morality. Article 1 of this law defines public morality as a system of ethical norms, rules of conduct that have developed in society on the basis of traditional spiritual and cultural values, ideas of goodness, honour, dignity, public duty, conscience, justice [8]. But, unfortunately, nowhere is it explained what should be recognized as "good" and what is the content of spiritual and cultural values, if the majority in society has forgotten about the spiritual traditions of their ancestors, lost faith in God. Also, the provisions of this law are unconstitutional, although they coincide with the requirements of the European Convention for the Protection of Human Rights and Fundamen- 
tal Freedoms. So in Part 2 of Art. 10 of the Convention states that that the exercise of human rights and freedoms may be subject to restrictions or sanctions that are necessary in a democratic society and in the interests of the latter 'for the protection of health or morals" [9]. However, in Part 2 of Art. 34 of the Constitution of Ukraine [10], which almost duplicates the content of Part 2 of Article 10 of the Convention, the provision on "protection of morality" is missing, which is an important shortcoming and inconsistency of national legislation with the European Convention. The lack of clear wording in the Law contributes to disorder, depriving a person of the opportunity to correct their behaviour. The Law of Ukraine "On Protection of Public Morality" was created to protect morality as the core of a spiritual being, unfortunately it does not perform this function, because it lacks many necessary factors that need attention such as: ignorance and disrespect for the elderly, parents, others; obscene remarks in public, etc. The above cannot serve as a restriction on freedom of expression for a person, because freedom in a state governed by the rule of law is possible only within the framework of observance of the law and respect for each other.

The state of morality in society will always be reflected in the legal arena of the state. The content of the "rule of law" must be filled with morality, because otherwise, the state can not be called legal. Morality and law are interconnected and indivisible components. Hence, we can say that morality has a stabilizing function in the rule of law. The stabilizing function of morality is to maintain the stability of the basic principles and rules of human life within the state through public resources, social, humanitarian, educational, propaganda and other methods of influence. Thus, the rule of law is endowed with a prognostic function with morality, because it determines the priorities of moral consciousness and culture of its citizens, which are based on the historical development of moral foundations and principles; reveals negative trends.

\section{Conclusions.}

Public morality in the history of all mankind is undergoing constant transformation. The impetus for moral transformation is all sorts of crises, external challenges, certain inconsistencies. The article substantiates the existence of a new category "stabilizing function of morality" as a new legal category, which is to maintain the stability of basic principles and rules of human life within the state through public resources, social, humanitarian, educational, propaganda and other methods of influence.

\section{References:}

1. Gregory A. Smith. A growing share of Americans say it's not necessary to believe in God to be moral. URL: https://www.pewresearch.org/facttank/2017/10/16/a-growing-share-of-americanssay-its-not-necessary-to-believe-in-god-to-bemorality / https://www.psychologytoday.com/intl/ basics/ethics-and-morality.

2. Public Becoming Less Religious. URL: https://www.pewforum.org/2015/11/03/us-public-becoming-less-religious/.

3. Religious Belief and National Belonging In Central And Eastern Europe. URL: https://www. pewforum.org/2017/05/10/social-views-andmorality/.

4. By Kim Parker and Ruth Igielnik. On the Cusp of Adulthood and Facing an Uncertain Future: What We Know About Gen Z So Far. (MAY 14, 2020). URL: https://www.pewsocialtrends.org/ essay/on-the-cusp-of-adulthood-and-facing-an-uncertain-future-what-we-know-about-gen-z-so-far/.

5. Being Christian In Western Europe. Religion and society. URL: https://www.pewforum. org/2018/05/29/religion-and-society/.

6. Ljupco Ristovski. Morality and Ethics in Politics in the Contemporary Societies. URL: $\quad$ https://www.researchgate.net/publication/316136859_Morality_and_Ethics_in_ Politics_in_the_Contemporary_Societies.

7. Lesya Pagulich, Halyna Yarmanova, Hanna Hrytsenko. Gender, Religion and Nationalism in Ukraine P. 14 Kyiv: VTS PRINT LLC. 77 p. URL: https://ua.boell.org/sites/default/files/gender-religion-nationalism-in-ukraine-www.pdf.

8. Law of Ukraine "On Protection of Public Morality". URL: https://zakon.rada.gov.ua/laws/ show/1296-15\#Text.

9. European Convention for the Protection of Human Rights and Fundamental Freedoms. URL: https://zakon.rada.gov.ua/laws/show/995 004\#Text.

10. Constitution of Ukraine. URL: extzakon. rada.gov.ua/laws/show/254к/96-вр\#T.

Вероніка Горєлова. Концептуальні тенденції сучасної моралі у правовому суспільстві

Стаття присвячена аналізу сучасного стану моралі у правовому суспільстві. Трансформація змісту моралі є особливим станом у рухливому процесі суспільного розвитку та прогресує на зламі політичних $і$ сочіально-економічних перетворень. Можна сказати, що трансформачія моралі у праві - це перетворення суспільної думки різного значення та спрямованості, що внаслідок внутрішніх або зовнішніх факторів або їх комбінащї відтворені в нормах права. Трансформащія моралі відбувається на певних етапах розвитку суспільства, а особливо тоді, коли люди дуже чутливо реагують на будь-які зовнішні зміни. Така трансформація моралі не може існувати поза межами 
права і не позначатися на його змісті. У статті досліджуються сучасні тендениї трансформаціі моралі у правовому суспільстві, що породжують нові теоретичні конструкиії та підходи у відносинах у суспільстві $і$, таким чином, підштовхують до модернізаиї правові скрижалі. Проаналізовані матеріали статистичних досліджень стосовно поглядів на мораль молодого покоління та людей стариого віку. Простежена тендениія поступової деградації моральних устоїв. У статті зазначено, що певні положення Закону Украйни «Про захист суспільної моралі» є неконституиійними, хоча i збігаються з вимогами Свропейської Конвениї про захист прав людини і основоположних свобод. Робиться акиент на тому, що Закон України «Про захист суспільної моралі» не виконує покладену на нього функиію, адже його положення не повинні сприйматися як обмеження свободи самовираження для людини, оскільки свобода у правовій державі можлива лише в рамках дотримання закону і норм моралі. Зміст категорії «правова держава» передбачає наповнення правових норм иілою низкою моральних приниипів та устоїв, адже в іншому разі держава не зможе називатися правовою. У статті обтрунтовано та запропоновано категорію «стабілізачійна функція моралі» як нова моральноправова категорія, яка полягає у підтримиі стійкості основних приниипів і правил людського життя всередині держави за рахунок державних ресурсів, сочіальних, гуманітарних, навчальних, агітачійних та інших методів впливу.

Ключові слова: трансформація моралі, стабілізаційна функція моралі, закон, моральні стандарти, добро, зло. 